\title{
Role of proteinase-activated receptor-2 in allergic sensitization to house dust mite allergens
}

\author{
Courtney Davidson ${ }^{1 *}$, Danny Polley², Muhammad Asaduzzaman ${ }^{1}$, Narcy Arizmendi ${ }^{1}$, John R Gordon³, \\ Morley D Hollenberg ${ }^{2}$, Harissios Vliagoftis ${ }^{1}$ \\ From Canadian Society of Allergy and Clinical Immunology Annual Scientific Meeting 2011 \\ Quebec, Canada. 20-23 October 2011
}

\section{Background}

A number of common aeroallergens have serine proteinase activity, which is important for allergic sensitization. House dust mite (HDM), and other allergens with serine proteinase activity activate Protease-Activated Receptor-2 (PAR-2). We have shown that PAR-2 activation in the airways leads to allergic sensitization to concomitantly inhaled antigens, implicating PAR-2 in the pathogenesis of asthma. We hypothesized that PAR-2 activation in the airways by HDM allergens is important for the development of allergic sensitization.

\section{Methods}

HDM extract was administered to mice intranasally for 5 consecutive days to induce allergic sensitization. One group of mice received a blocking anti-PAR-2 antibody intranasally before each HDM administration.

\section{Results}

Administration of the PAR-2 blocking antibody decreased IL-4, IL13 and IL-33 mRNA as well as IL-4, IL-5 and MIP1A protein levels in the lung tissue, suggesting decreased allergic airway sensitization. Mice sensitized in the presence of the PAR-2 blocking antibody or isotype control were then challenged intranasally with HDM extract for 4 consecutive days. Mucosal exposure to HDM extract induced AHR and airway eosinophilic inflammation. Administration of the anti-PAR-2 blocking antibody during the sensitization phase completely inhibited the development of AHR and airway inflammation in response to HDM challenge.
'Pulmonary Research Group, Department of Medicine, University of Alberta, Edmonton, AB Canada

Full list of author information is available at the end of the article

\section{Conclusions}

These results indicate that HDM extract induces PAR-2dependent allergic sensitization in mice and lead to PAR-2-dependet allergic airway inflammation. These results will allow us to better define the mechanisms of allergic sensitization to allergens with serine proteinase activity.

\section{Author details}

${ }^{1}$ Pulmonary Research Group, Department of Medicine, University of Alberta, Edmonton, AB Canada. ${ }^{2}$ Department of Pharmacology and Therapeutics, University of Calgary, Calgary, AB Canada. ${ }^{3}$ Immunology Research Group, University of Saskatchewan, Saskatoon, Saskatchewan, Canada.

Published: 14 November 2011

doi:10.1186/1710-1492-7-S2-A30

Cite this article as: Davidson et al:: Role of proteinase-activated

receptor-2 in allergic sensitization to house dust mite allergens. Allergy, Asthma \& Clinical Immunology 2011 7(Suppl 2):A30.

Submit your next manuscript to BioMed Central and take full advantage of:

- Convenient online submission

- Thorough peer review

- No space constraints or color figure charges

- Immediate publication on acceptance

- Inclusion in PubMed, CAS, Scopus and Google Scholar

- Research which is freely available for redistribution

Submit your manuscript at www.biomedcentral.com/submit
() Biomed Central

\section{Biomed Central}

